
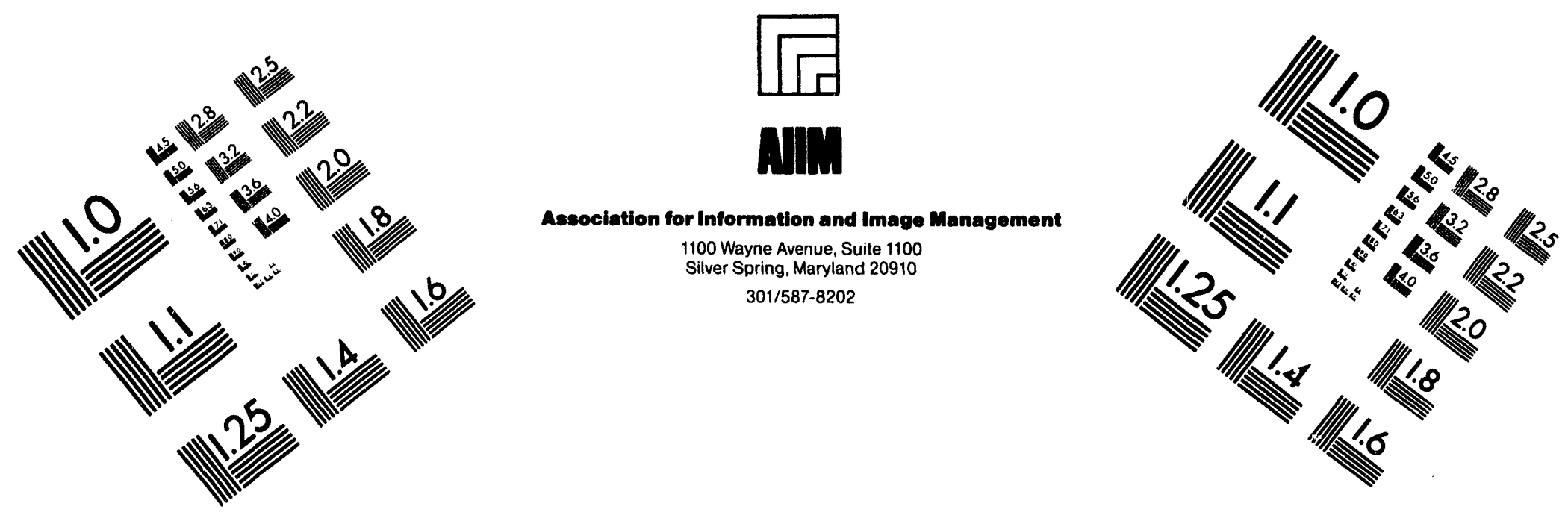

\title{
Centimeter
}

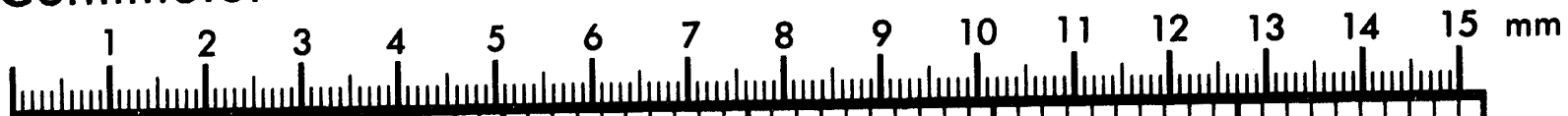

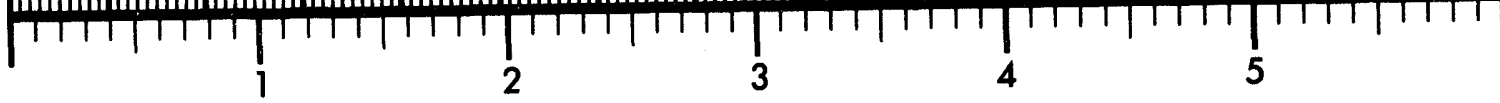
Inches
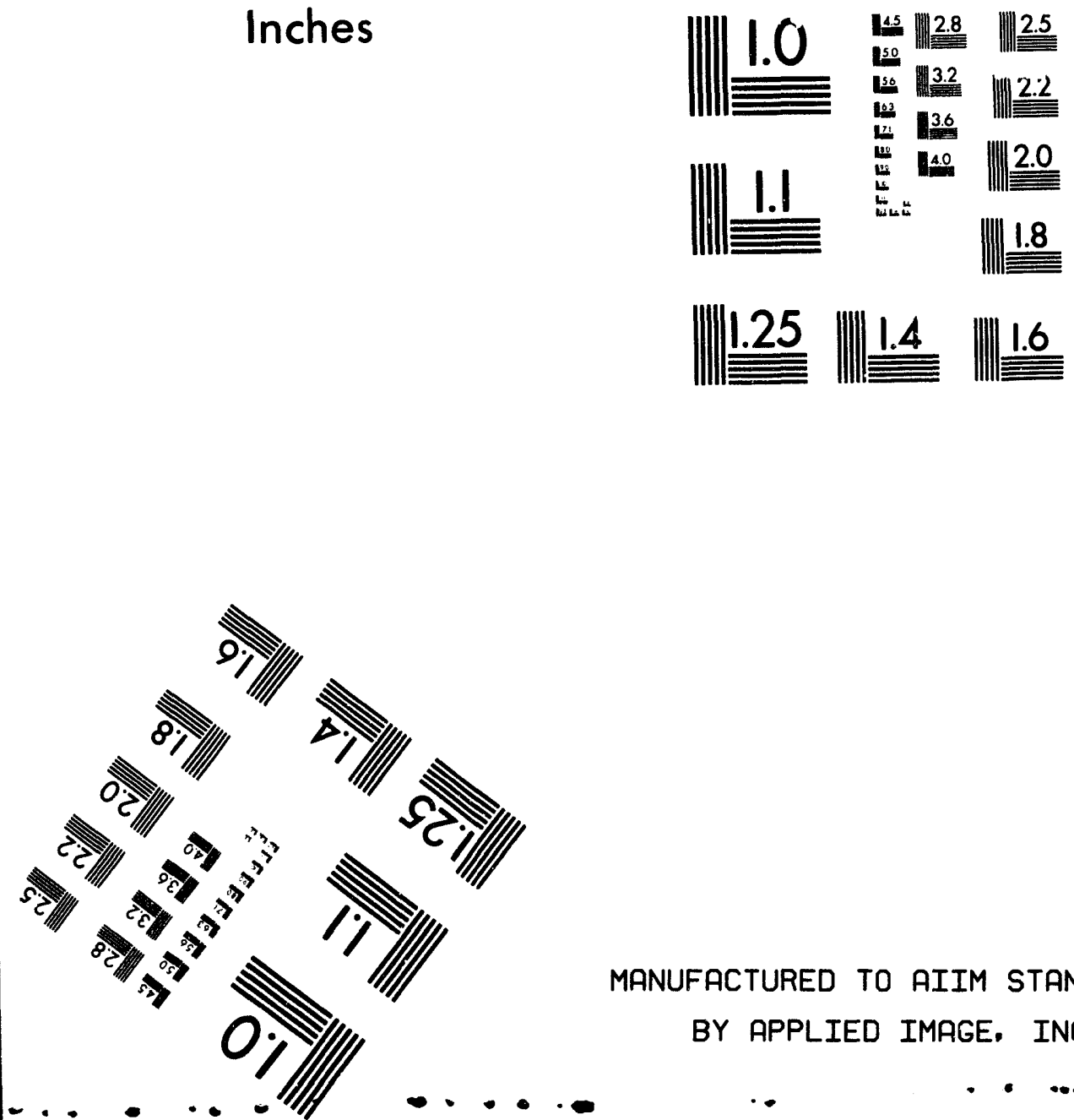

MANUFACTURED TO AIIM STANDARDS

BY APPLIED IMAGE, INC.

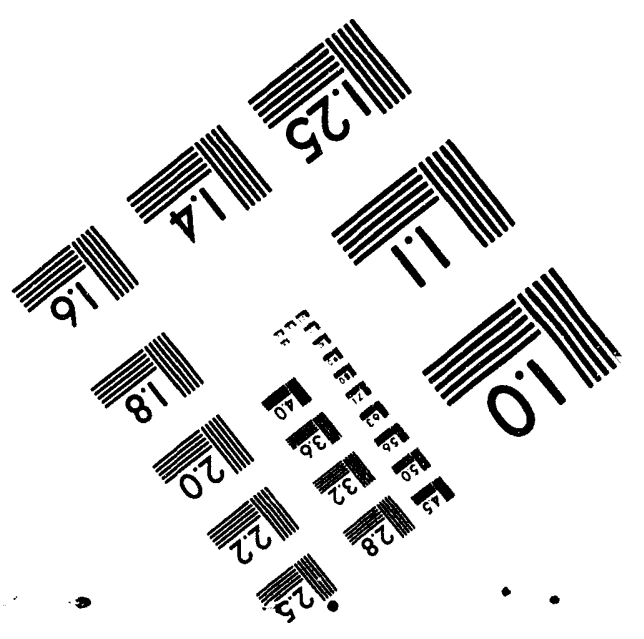




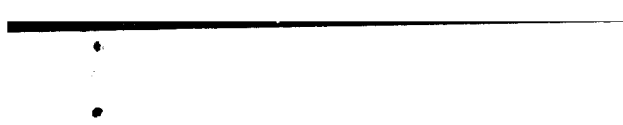

is

-

8

:

:

,

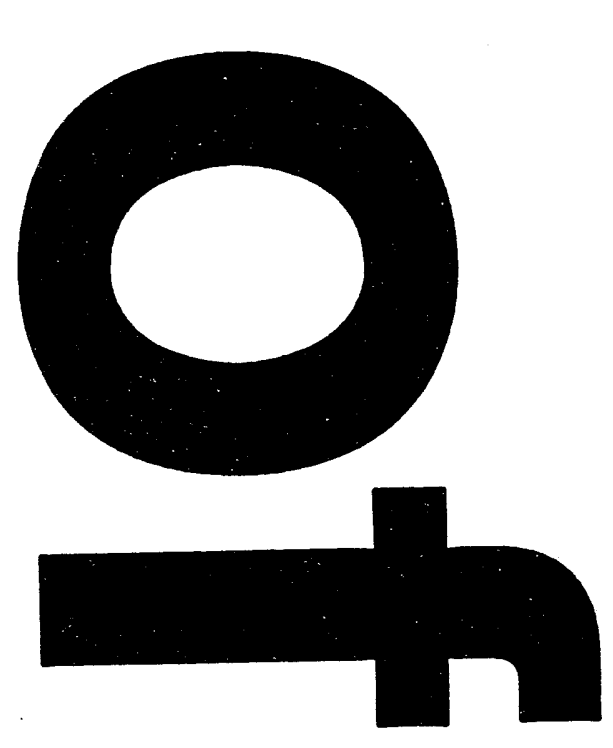



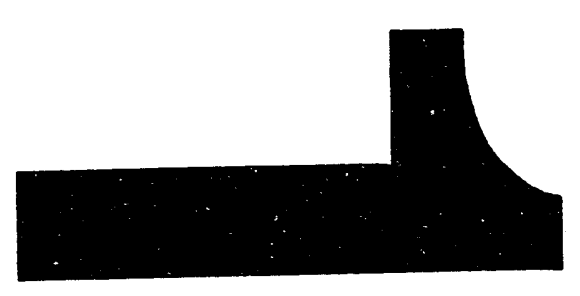




\section{Effects of Piston Surface Treatments on Performance and Emissions of a Methanol-Fueled, Direct Injection, Stratified Charge Engine}

B. West

J. B. Green

Oak Ridge National Laboratory

Oak Ridge, Tennessee

NREL technical monitor: C. Colucci

National Renewable Energy Laboratory 1617 Cole Boulevard Golden, Colorado 80401-3393

A national laboratory of the U.S. Department of Energy Operated by Midwest Research Institute for the U.S. Department of Energy

Under Contract No. DE-AC36-83CH10093

Prepared under Subcontract Number DZ-2-11166-1

July 1994

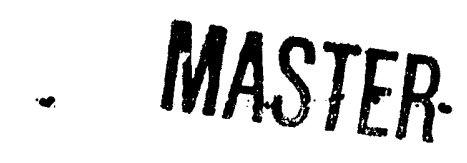




\section{NOTICE}

NOTICE: This report was prepared as an account of work sponsored by an agency of the United States govemment. Neither the United States government nor any agency thereof, nor any of their mployees, makes any warranty, express or implied, or assumes any legal liability or responsibility for the accuracy, completeness, or usefulness of any information, apparatus, product, or process disclosed, or represents that its use would not infringe privately owned rights. Reference herein to any specific commercial product, process, or service by trade name, trademark, manufacturer, or otherwise does not necessarily constitute or imply its endorsement, recommendation, or favoring by the United States government or any agency thereof. The views and opinions of authors expressed herein do not necessarily state or reflect those of the United States government or any agency thereof.

Printed in the United States of America

Available to DOE and DOE contractors from:

Office of Scientific and Technical Information (OSTI)

P.O. Box 62

Oak Ridge, TN 37831

Prices available by calling (615) $576-8401$

Available to the public from:

National Technical Information Services (NTIS)

U.S. Department of Commerce

5285 Port Royal Road

Springfield, VA 22161

(703) $487-4650$ 


\section{Contents}

Introduction $\ldots \ldots \ldots \ldots \ldots \ldots \ldots \ldots \ldots \ldots \ldots \ldots \ldots \ldots \ldots \ldots \ldots \ldots \ldots$



Description of the Experiment $\ldots \ldots \ldots \ldots \ldots \ldots \ldots \ldots \ldots \ldots \ldots \ldots \ldots \ldots \ldots$

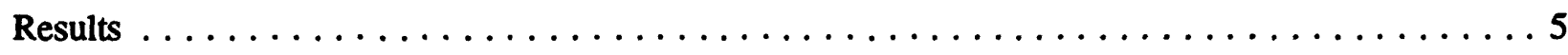

Summary and Conclusions $\ldots \ldots \ldots \ldots \ldots \ldots \ldots \ldots \ldots \ldots \ldots \ldots \ldots \ldots \ldots \ldots$

Acknowledgments $\ldots \ldots \ldots \ldots \ldots \ldots \ldots \ldots \ldots \ldots \ldots \ldots \ldots \ldots \ldots \ldots \ldots \ldots$

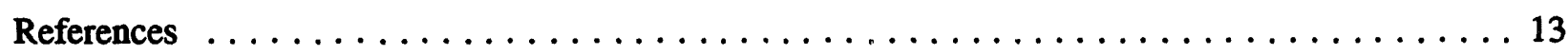

\section{List of Figures}

Figure 1. Modified piston and bowl inserts: (a) section view with air-gap insert and (b) piston



Figure 2. Brake thermal efficiency at $1800 \mathrm{rpm}$ for four piston insert surfaces $\ldots \ldots \ldots \ldots$

Figure 3. Brake thermal efficiency at $1400 \mathrm{rpm}$ for four piston insert surfaces $\ldots \ldots \ldots \ldots$

Figure 4. Average volumetric efficiency at two engine speeds for four piston insert surfaces $\ldots \ldots 7$

Figure 5. Emissions index $\mathrm{HC}$ at $1800 \mathrm{rpm}$ for four piston insert surfaces $\ldots \ldots \ldots \ldots \ldots$

Figure 6. Emissions index $\mathrm{HC}$ at $1400 \mathrm{rpm}$ for four piston insert surfaces $\ldots \ldots \ldots \ldots$

Figure 7. Emissions index $\mathrm{NO}_{\mathrm{x}}$ at $1800 \mathrm{rpm}$ for four piston insert surfaces $\ldots \ldots \ldots \ldots$

Figure 8. Emissions index $\mathrm{NO}_{\mathrm{x}}$ at $1400 \mathrm{rpm}$ for four piston insert surfases $\ldots \ldots \ldots \ldots$

Figure 9. Emissions index $\mathrm{HC}$ versus emissions index $\mathrm{NO}_{x}$ at $1800 \mathrm{rpm}$ for four piston insert

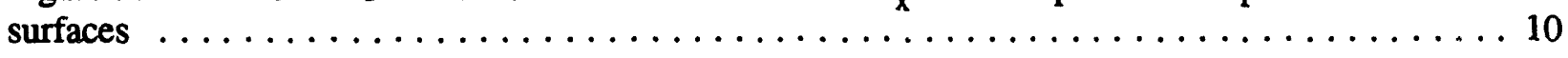

Figure 10. Emissions index $\mathrm{HC}$ versus emissions index $\mathrm{NO}_{x}$ at $1400 \mathrm{rpm}$ for four piston

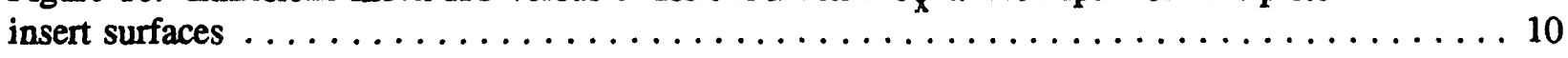

Figure 11. Stainless steel/air-gap insert with TEMPLUGS installed $\ldots \ldots \ldots \ldots \ldots$ 


\section{Introduction}

The purpose of this study was to investigate the effects of thermal barrier coatings and/or surface treatments on the performance and emissions of a methanol-fueled, direct-injection, stratified-charge (DISC) engine. A Ricardo Hydra Mark III engine was used for this work and in previous experiments at Oak Ridge National Laboratory (ORNL) (Kahl 1989). The primary focus of the study was to examine the effects of various piston insert surface treatments on hydrocarbon $(\mathrm{HC})$ and oxides of nitrogen $\left(\mathrm{NO}_{\mathrm{x}}\right)$ emissions. Previous studies have shown that engines of this class have a tendency to perform poorly at low loads and have high unburned fuel emissions (Kahl 1989; Giovanetti et al. 1983).

A blank aluminum piston was modified to employ removable piston bowl inserts, as shown in Figure 1. Four different inserts were tested in the experiment: aluminum, stainless steel with a $1.27-\mathrm{mm}(0.050$-in.) air gap (to act as a thermal barrier), and two stainless steel/air-gap inserts with coatings. Two stainless steel inserts were dimensionally modified to account for the coating thickness $(1.27-\mathrm{mm})$ and coated identically with partially stabilized zirconia (PSZ). One of the coated inserts then had an additional sealcoat applied. The coated inserts were otherwise identical to the stainless steel/air-gap insert (i.e., they employed the same 1.27-mm air gap). Thermal barrier coatings were employed in an attempt to increase combustion chamber surface temperatures, thereby reducing wall quenching and promoting more complete combustion of the fuel in the quench zone. The seal-coat was applied to the zirconia to reduce the surface porosity; previous research suggested that despite the possibly higher surface temperatures obtainable with a ceramic coating, the high surface area of a plasma-sprayed coating may actually allow fuel to adhere to the surface and increase the unburned fuel emissions and fuel consumption (Kahl 1989; Beardsley and Larson 1992).

\section{Background}

The DISC engine is a hybrid engine; it possesses characteristics of both diesel and spark-ignition engines. The DISC engine is unthrottled; hence the load is a function of the amount of fuel injected per cycle (for a given engine speed) only "and the air inducted into the engine is a function of engine speed only. The DISC engine has two distinct advantages: operation on many different fuels as a result of fiel tolerance (e.g., it can burn low-octane fuels despite the high compression ratio), and improved part-load fuel economy as a result of unthrottled operation and overall lean operation (Norris-Jones and Russell 1982; Wood 1978).

The DISC engine utilizes intake-generated swirl and fuel jet momentum to keep a stratified stream of fuelrich mixture moving across the spark plug during ignition. The spark initiates combustion in the fuel-rich stream, creating a flame that ignites the swirling mixture of fuel and air contained within the piston bowl. Swirl is caused by a helical port design and is intensified by squish. Squish is caused by the radial motion of gas into the piston bowl toward the end of the compression stroke as the piston moves toward top dead center (TDC). Theoretically, an engine of this class should exhibit appreciable part-load fuel economy that is superior to that of a throttled spark-ignition engine because of the combination of a low fuel-air ratio, high compression ratio, and absence of throttling (Norris-Jones and Russell 1982; Wood 1978; Heywood 1988).

A disadvantage of DISC engines is that they are prone to higher unburned fuel emissions at low loads than are homogeneous-charge engines. This is primarily because of fuel jet diffusion at low fueling rates. This diffusion produces regions with fuel-air mixtures that are too lean to burn completely (Wood 1978). It has also been observed that either wall quenching or fuel impingement on the piston bowl surface can be a mechanism for producing HC emissions in an engine of this type (Frank and Heywood 1991). 

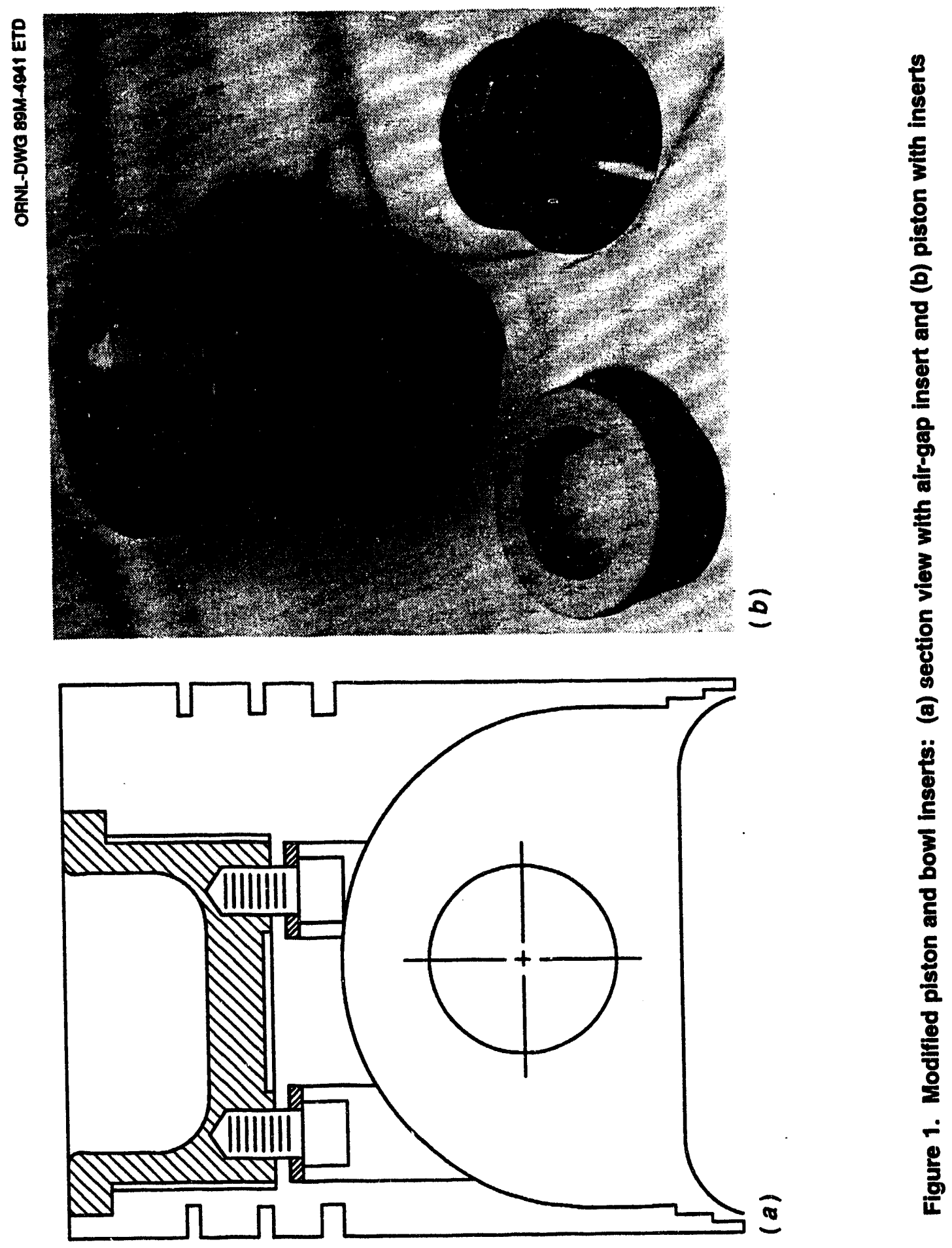


\section{Description of the Experiment}

The engine used in the experiments was a Ricardo Hydra Mark III single-cylinder research engine (Table 1). The DISC combustion system used by Ricardo was the MAN-FM system of Maschinenfabrik Augsburg-Nurnberg (Norris-Jones and Russell 1982). The MAN-FM system uses a spherical chamber in the piston, with direct fuel injection like a diesel, and a spark plug for ignition. This particular engine's original MAN-FM piston was destroyed during a previous experiment, so the engine was baselined with an aluminum piston insert. The removable inserts maintain the same combustion chamber volume as the spherical chamber in the MAN-FM piston, but with a more cylindrical (as opposed to spherical) geometry. The shape of this pseudo-cylindrical design actually somewhat paralleled subsequent development efforts by MAN in their own methanol-fueled bus engines (Kahl 1989).

Table 1. Ricardo Engine Specifications

\begin{tabular}{|c|c|}
\hline Bore & $9.4 \mathrm{~cm}$ \\
\hline Stroke & $9.0 \mathrm{~cm}$ \\
\hline Displacement & $625 \mathrm{~cm}^{3}$ \\
\hline Compression ratio & 13.2:1 \\
\hline Cylinder block & $\begin{array}{l}\text { Cast iron with steel wet cylinder liner, separate } \\
\text { cooling }\end{array}$ \\
\hline Cylinder head & Aluminum with separate cooling \\
\hline Combustion chamber & $\begin{array}{l}\text { Bowl-in-piston inserts, } 304 \text { stainless-steel or } \\
\text { aluminum }\end{array}$ \\
\hline Valve train & Belt-driven, single overhead cam (SOHC) \\
\hline Injection & $\begin{array}{l}\text { Bosch PE4A injection pump (belt-driven), CAV } \\
\text { LR pintle-type nozzle with } 0.62-\mathrm{mm} \text { needle lift }\end{array}$ \\
\hline Ignition & $\begin{array}{l}\text { Autotronics MSD-6A multistrike electronic } \\
\text { ignition with magnetic trigger, electronic retard, } \\
\text { triple electrode spark plug }\end{array}$ \\
\hline
\end{tabular}

In previous studies, the engine was fueled with M85 (85 volume \% methanol, 15 volume \% unleaded gasoline). For this study, M100 (pure methanol), with $0.06 \%$ Lubrizol lubricity additive, was used because heavy-duty engine manufacturers have concentrated on M100 as an alternative fuel and because using M100 simplifies exhaust gas speciation. Start of injection for all engine builds was around $42^{\circ}$ BTDC (crank angle degrees before top dead center), with a duration of around $25^{\circ}$ at light loads, and spark timing was about $22^{\circ}$ BTDC. The multistrike ignition system used with this engine results in an effective spark duration of $35^{\circ}-40^{\circ}$ at 1800 revolutions per minute (rpm).

The thermal barrier coating used was an $8 \%$ yttria, PSZ, with a NiCrAlY bond coat. Zirconia was chosen as a thermal barrier because of its low thermal conductivity and relatively high coefficient of thermal expansion (compared with those of some other ceramics), and 304 stainless steel was chosen as the base material because of its low thermal conductivity and corrosion resistance. The NiCrAlY bond coat acts to lessen thermal stresses in the coating; for example, its coefficient of thermal expansion is between that of the base material and the coating. The zirconia coatings were applied by Plasma Technology 
Thermo-Environmental FID. Flame ionization detectors are typically calibrated using propane, and measurements are manipulated using response factors for the various constituents in the exhaust. Flame ionization detectors are known to respond only partially to methanol in exhaust gas, so a standard gas with known methanol concentration was used for calibration. This is a reasonable approach because methanol typically accounts for some $90 \%-95 \%$ of fuel-related emissions from direct-injection, methanol-fueled engines (Lipari and Keski-Hynnila 1986). A Beckman $951 \mathrm{NO} / \mathrm{NO}_{\mathrm{x}}$ analyzer was used for measuring the $\mathrm{NO}_{\mathrm{x}}$ emissions.

\section{Results}

\section{Effects of Piston Insert Materials}

Figure 2 shows the brake thermal efficiency as a function of brake mean effective pressure (BMEP) for the four engine builds at $1800 \mathrm{rpm}$. The curves shown in the figure are to aid the reader in comparing the data sets and are of the simplest order that would show the expected trends. While no single piston insert shows an appreciable improvement in thermal efficiency, the PSZ coating appears to improve efficiency at high loads, although the scatter in the data preclude making this observation with a high level of confidence. The thermal efficiency at a lower speed $(1400 \mathrm{rpm})$ is shown in Figure 3. Again, all four inserts perform equally well.

Figure 4 shows the average volumetric efficiency for each of the four builds at both engine speeds. The volumetric efficiency is defined as the actual air consumption rate divided by the theoretical air consumption rate (displacement per revolution times $\mathrm{rpm}$ ). Note that the best volumetric efficiency is achieved with the baseline aluminum insert. Use of the stainless-steel/air-gap insert seems to degrade the volumetric efficiency, and the zirconia coating appears to degrade it further. The loss in volumetric efficiency is undoubtedly caused by the higher in-cylinder temperatures with the use of these piston inserts. Using measured cylinder pressure at similar conditions for each build (half load, $15^{\circ}$ ATDC), the bulk cylinder temperature was estimated (using the ideal gas equation). Results of these calculations showed that the zirconia-coated insert yielded the highest bulk temperature, followed by the seal-coated zirconia, stainless steel/air gap, and aluminum, respectively. The calculated bulk temperatures for the sealcoat and stainless steel/air gap inserts were nearly the same, and as shown in Figure 4, their volumetric efficiencies are very similar.

Emissions index hydrocarbons (EIHC) at $1800 \mathrm{rpm}$ are shown in Figure 5. The stainless steel/air-gap piston insert clearly produces the lowest unburned fuel emissions, followed by the seal-coated and aluminum and zirconia-coated inserts. These results support the presumption that the zirconia coating may trap fuel during the combustion process and release it during blowdown, resulting in higher unburned fuel emissions (Kahl 1989; Beardsley and Larson 1992). The seal-coating (surface densification) had the expected effect of improving the performance of the zirconia coating, but the emissions were still higher than those with the stainless steel/air-gap insert. Unburned fuel emissions for the zirconia-coated insert are similar to those with bare aluminum. Figure 6 shows the HC emissions at $1400 \mathrm{rpm}$. Differences in the aluminum, zirconia, and seal-coat are not clear at the lower speed, but the stainless-steel/air-gap insert is still the superior configuration tested in this engine. It is evident that simply increasing the cylinder temperature via surface coatings is not sufficient to alleviate unburned fuel emissions. These emissions levels are unusually high for even a DISC engine. In fact, Frank and Heywood have published HC emissions on the order of 20 to $40 \mathrm{~g} / \mathrm{kg}$ fuel at light loads in a similar engine, albeit on gasoline fuel (Frank and Heywood 1991). Reasons for this particular engine's poor performance are unclear. 




Figure 2. Brake thermal efficiency at $1800 \mathrm{rpm}$ for four piston insert surfaces

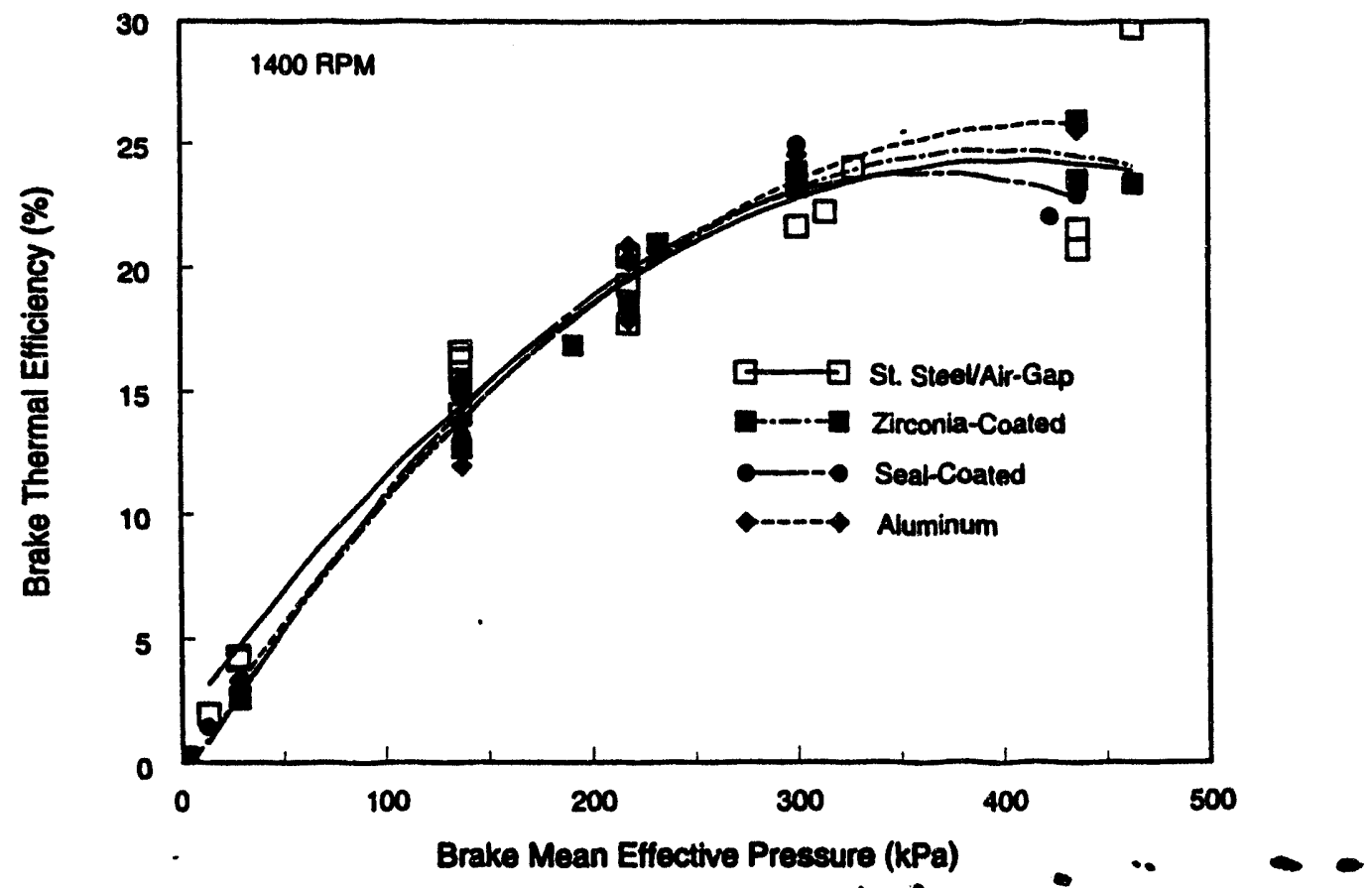

Figure 3. Brake thermal efficiency at $1400 \mathrm{rpm}$ for four piston insert surfaces 


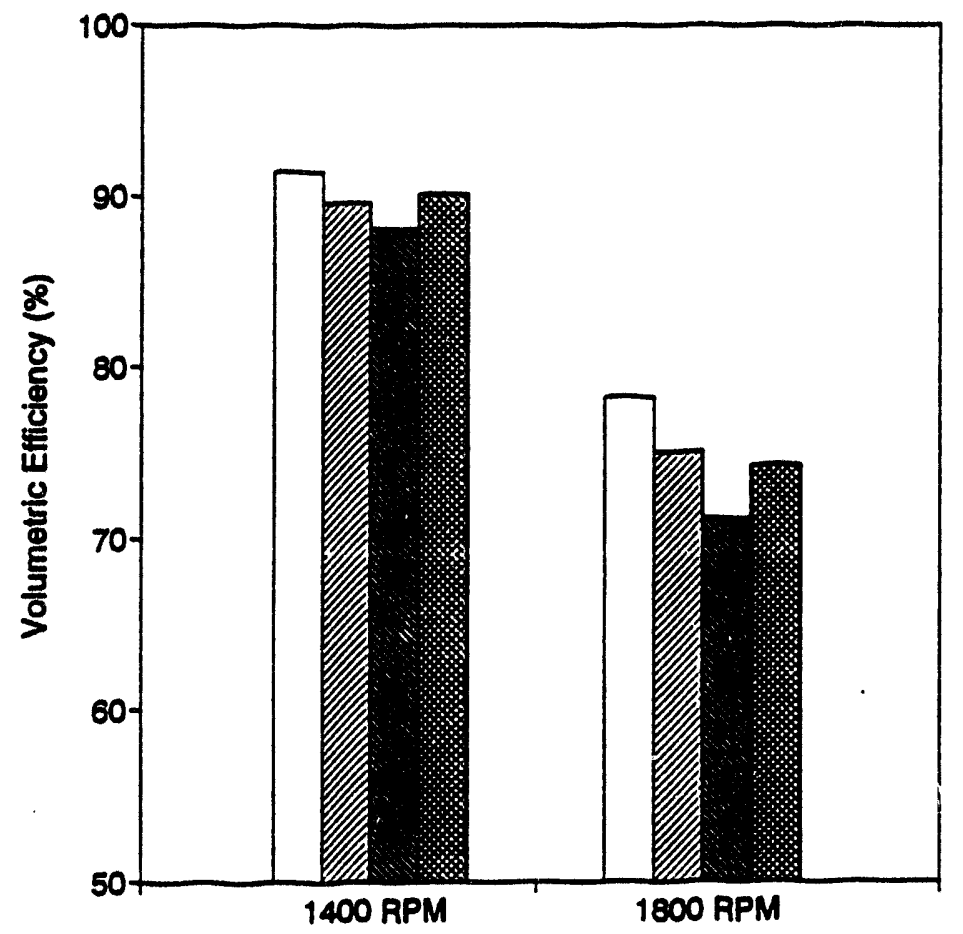

\begin{tabular}{|l|}
\hline \\
\hline Aluminum \\
We \\
Steel/Air-Gap \\
Zirconia-Coated \\
Zirco \\
Seal-Coated \\
\hline
\end{tabular}

Figure 4. Average volumetric efficiency at two engine speeds for four piston insert surfaces

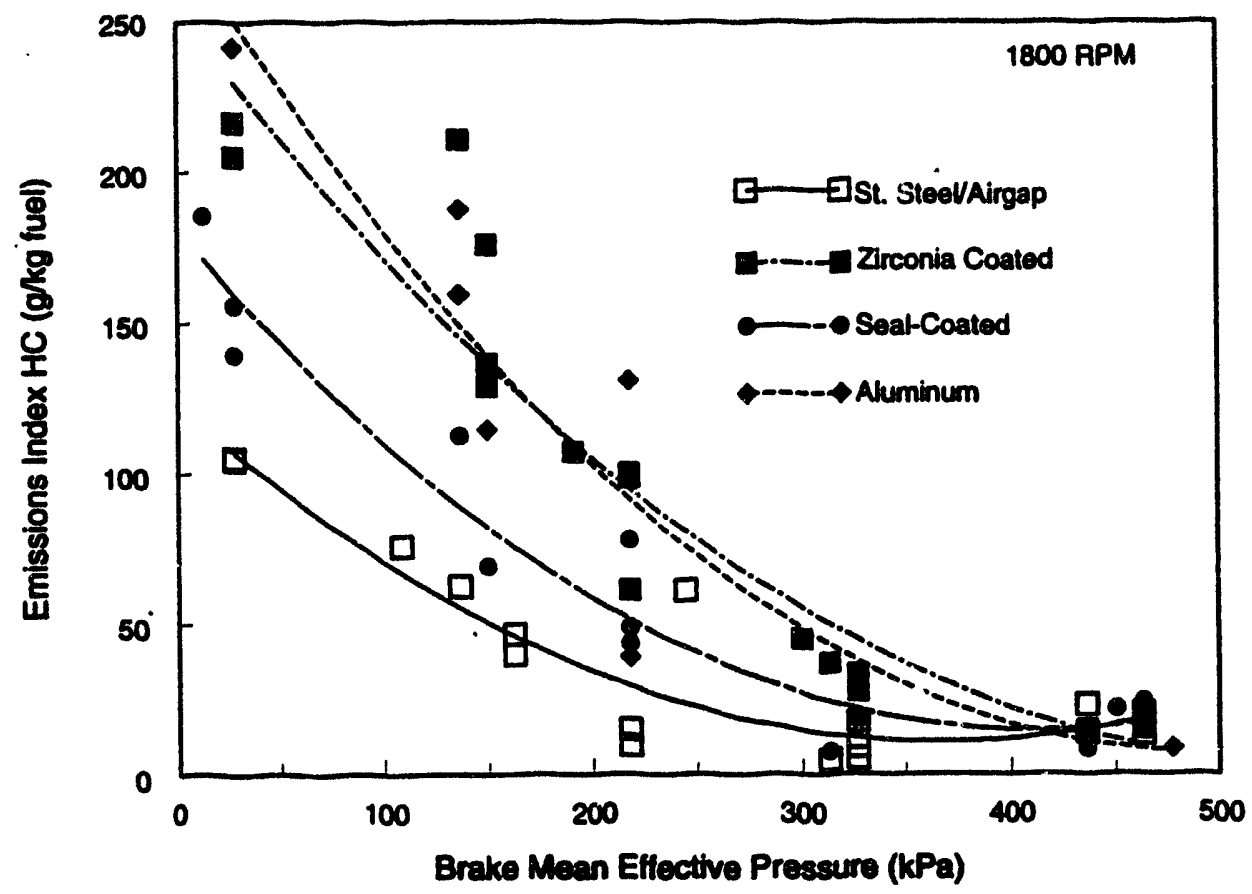

Figure 5. Emiasions.indox HC at 1800 mpn for fourploton insert surtices 




Figure 6. Emissions index HC at $1400 \mathrm{rpm}$ for four piston insert surfaces

Figures 7 and 8 show that the $\mathrm{NO}_{\mathrm{x}}$ emissions are highest for the stainless steel/air-gap insert, followed by the aluminum, seal-coat, and zirconia-coated inserts, with little or no discernible difference. Given that the stainless-steel/air-gap insert produced the lowest unburned fuel emissions, one might expect higher $\mathrm{NO}_{\mathrm{x}}$ emissions. Oxides of nitrogen emissions are generally attributed to higher combustion temperatures. Although the data indicate higher bulk temperatures for the coated inserts, local combustion temperatures were evidently highest for the stainless steelair-gap insert. In premixed flames, maximum $\mathrm{NO}_{\mathrm{x}}$ is typically formed when the air:fuel ratio is just lean of stoichiometric. Diffusion burning typically yields lower $\mathrm{NO}_{\mathrm{x}}$ because the locally rich mixtures are cooler and there is a lack of excess oxygen available for $\mathrm{NO}_{x}$ conversion. Rich premixed flames or excessively lean premixed flames also produce low $\mathrm{NO}_{x}$ emissions. Fuel evaporation off of the piston bowl surface might possibly be occurring at the highest rate with the stainless-steel/air-gap insert. The air-gap insulation around this-insert could enable it to store substantial thermal energy that more rapidly vaporizes the fuel film on the piston bowl surface, leading to more premixed flame combustion near stoichiometry, and higher $\mathrm{NO}_{x}$ emissions. The thermal barrier coatings have low heat capacity, and might be quenched quickly by the fuel spray. This low heat capacity combined with low thermal conductivity might preclude rapid heating of the fuel film, resulting in combustion at more locally rich conditions, and lower $\mathrm{NO}_{\mathrm{x}}$.

Figures 5 and 6 show that the EIHC as a function of BMEP are lowest for the stainless steel/air-gap piston insert at light loads, and Figures 7 and 8 show that this configuration yields the highest emission index oxides of nitrogen (EINO $)$ ). A well-accepted premise is that most engines exhibit a $\mathrm{HC}_{-} \mathrm{NO}_{\mathrm{z}}$ tradeoff, e.g., these emissions constituents are inversely proportional. Increases in $\mathrm{HC}$ emissions because of changes in load, spark timing (in a homogeneous charge engine), or injection timing (in a diesel engine) generally result in declines in $\mathrm{NO}_{x}$ emissions, and vice-versa. Emissions index $\mathrm{HC}$ are plotted as a function of $\mathrm{ENO}_{\mathrm{x}}$ in 1 Figures 9 and 10. The $\mathrm{HC}-\mathrm{NO}_{\mathrm{x}}$ tradeoff is apparent in these figures. Again, the highest $\mathrm{NO}_{\mathrm{x}}$ and lowest HC emissions are apparent for the stainless steel/air-gap insert. 


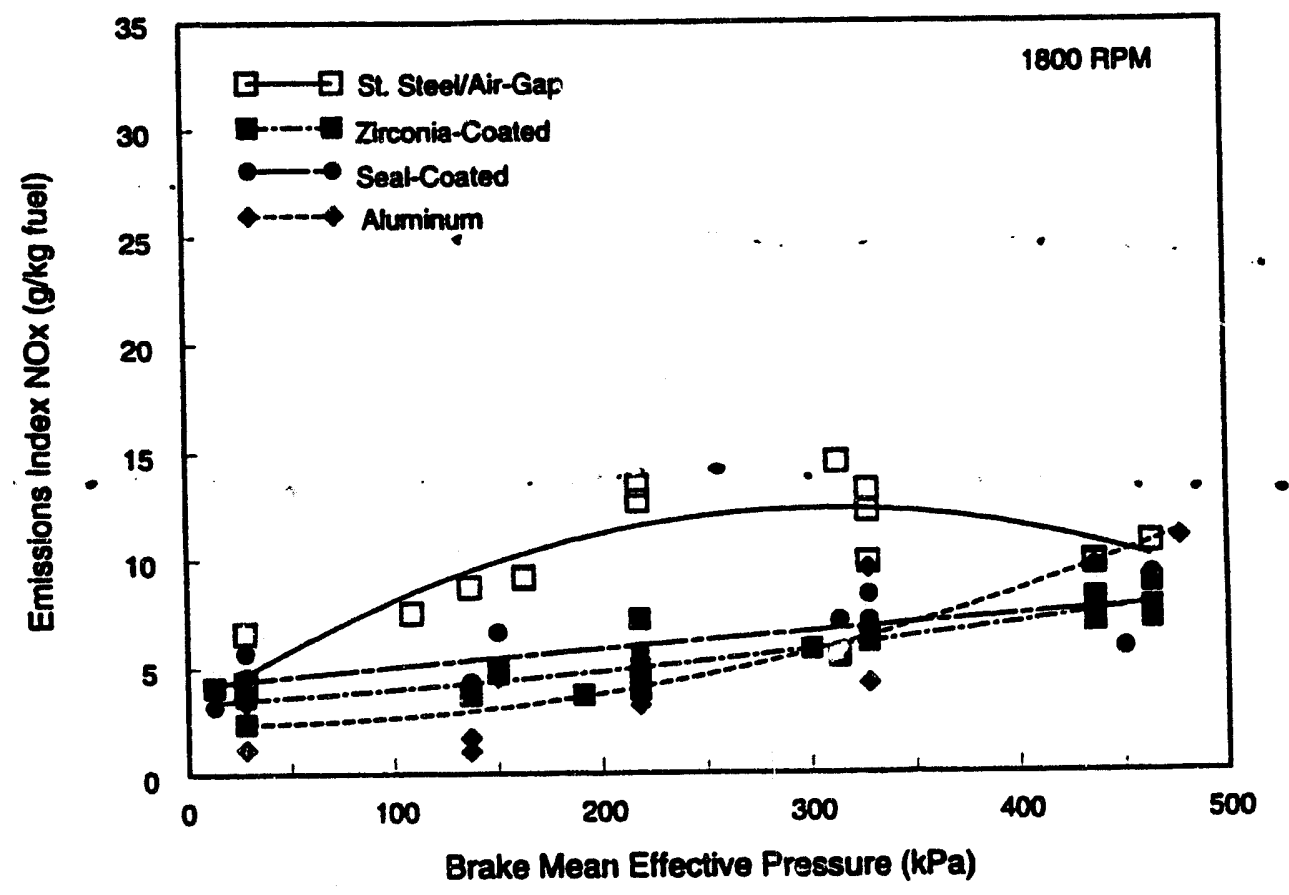

Figure 7. Emissions index NO at $1800 \mathrm{rpm}$ for four piston insert surfaces



Figure 8. Emissions index $\mathrm{NO}_{\mathrm{z}}$ at $1400 \mathrm{mpm}$ for four piston insert surfaces 


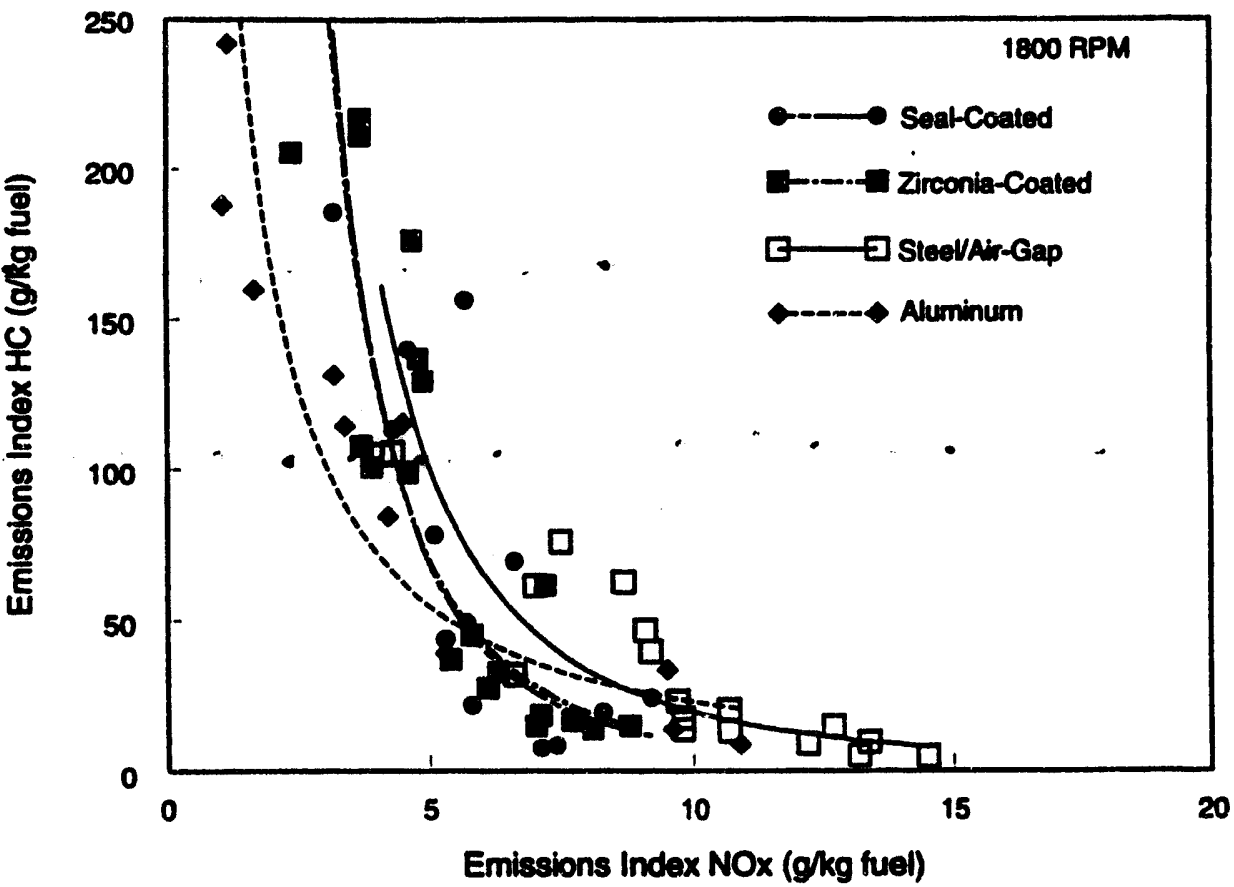

Figure 9. Emissions index $\mathrm{HC}$ versus emissions index $\mathrm{NO}_{\mathrm{x}}$ at $1800 \mathrm{rpm}$ for four piston insert surfaces



Figure 10. Emisaions index HC versus emissions index $\mathrm{NO}_{\mathrm{x}}$ at $1400 \mathrm{rpm}$ for four piston inseart surfaces 


\section{In-Cylinder Catalysis}

The use of removable piston inserts in the Ricardo engine used in this research facilitates development and testing of catalytic coatings for in-cylinder use. A cooperative research and development agreement (CRADA) has been signed between ORNL and AC Rochester Division of General Motors (CRADA X92-0115): Under the terms of the CRADA, information regarding in-sylinder catalysis is proprietary to AC Rochester. Planning of engine experiments is currently under way, and AC Rochester is recommending catalyst materials for in-cylinder use.

. To help guide catalyst selection, piston-bowl surface temperature measurements were made utilizing-nine TEMPLUG temperature méasurement devices installed in a stainless steel/air-gap insert. TEMPLUGs are heat-treated steel setscrews with known thermal tempering (softening) characteristics. Nine TEMPLUGs were installed with their sensitive ends flush with the piston bowl surface, as shown in Figure 11. The engine was run at half-load for several minutes. Hardness testing after exposure showed that the TEMPLUGs had reached sustained peak temperatures averaging $620^{\circ} \mathrm{C}$, ranging from $540^{\circ}-720^{\circ} \mathrm{C}$. These measurements represent "bulk," or average temperatures of the piston insert, and actual temperatures during the combustion process are no doubt somewhat higher. Modern catalytic converters operate at $600^{\circ}-700^{\circ} \mathrm{C}$, so these results are encouraging for the prospects of in-cylinder catalysis.

\section{Summary and Conclusions}

A DISC engine was used to examine the effects of piston surface coatings on performance and emissions. A blank aluminum piston was modified to employ removable piston bowl inserts. An aluminum insert was used as the baseline case, approximating the MAN-FM combustion system. Modified bowls included a bare stainless-steel insert with a $1.27-\mathrm{mm}$ air gap, and two similar stainless steel/air-gap inserts coated with partially-stabilized zirconia. One of the two zirconia-coated inserts received a surface densification coating, or seal-coat. For the range of operation tested, the stainless-steel/air-gap insert produced the lowest EIHC, at the expense of higher $\mathrm{NO}_{\mathrm{x}}$ emissions. The zirconia-coated insert produced the highest EIHC and the lowest EINO. Unburned fuel emissions for the coated inserts were improved by the addition of the seal-coating. Thermal efficiency at high loads was improved using the thermal barriercoated inserts, while the baseline aluminum insert maintained the advantage at lighter loads.

While the DISC engine offers advantages such as fuel tolerance and the potential for superior fuel economy (because of unthrottled, lean operation), it is prone to high unburned fuel emissions at light loads. The experiments reported on here compare its performance with various piston inserts while keeping injection timing and ignition timing constant, and the results should be viewed in light of these facts. Although it was not in the scope of this project, piston bowl materials and coatings would be better compared when the engine has been optimized for each configuration. The experiments have shown that the use of coatings can actually degrade unburned fuel emissions, while improving oxides of nitrogen emissions. The use of piston surface treatments has been shown to alter the characteristic $\mathrm{HC}_{\mathrm{Vs}} \mathrm{NO}_{\mathrm{x}}$ tradeoff for this engine. Consequently, these surface treatments represent an additional design parameter which may be used to make the DISC engine a viable light-duty powerplant. These results also reinforce the importance of using seal-coats with sprayed coatings, as observed by other research teams. 


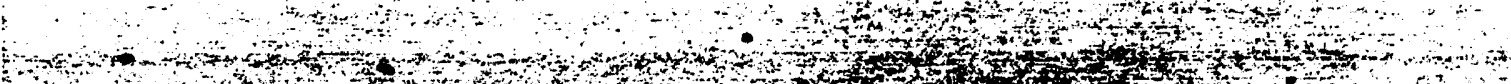

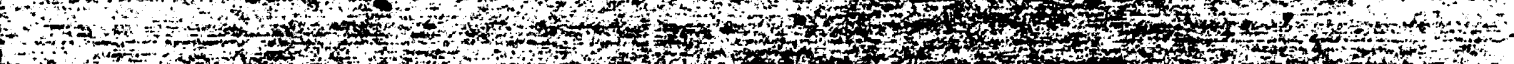

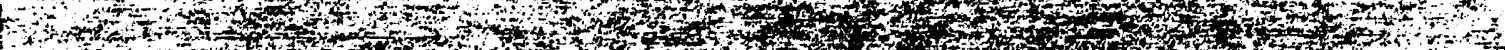

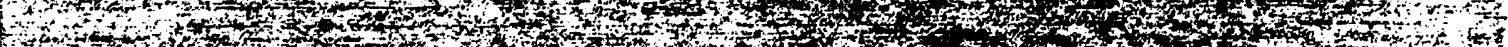

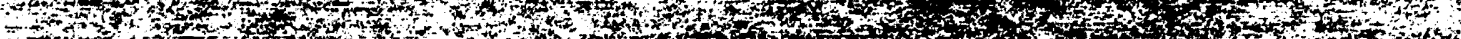

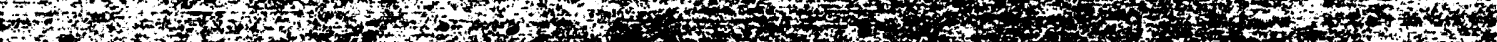

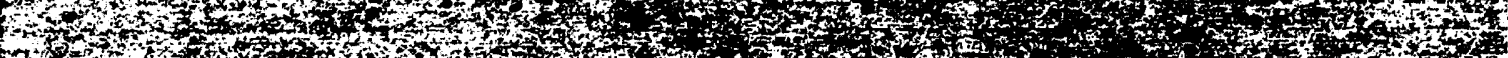

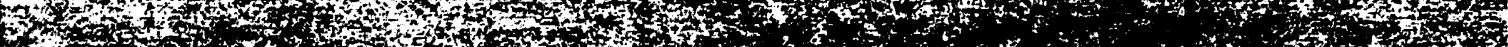

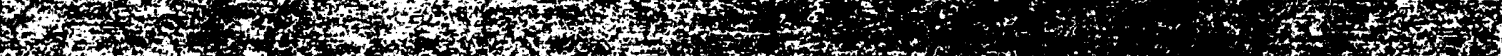
-

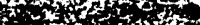

$\rightarrow+2 x$

30 o

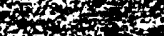

3 at



$5+5$

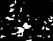

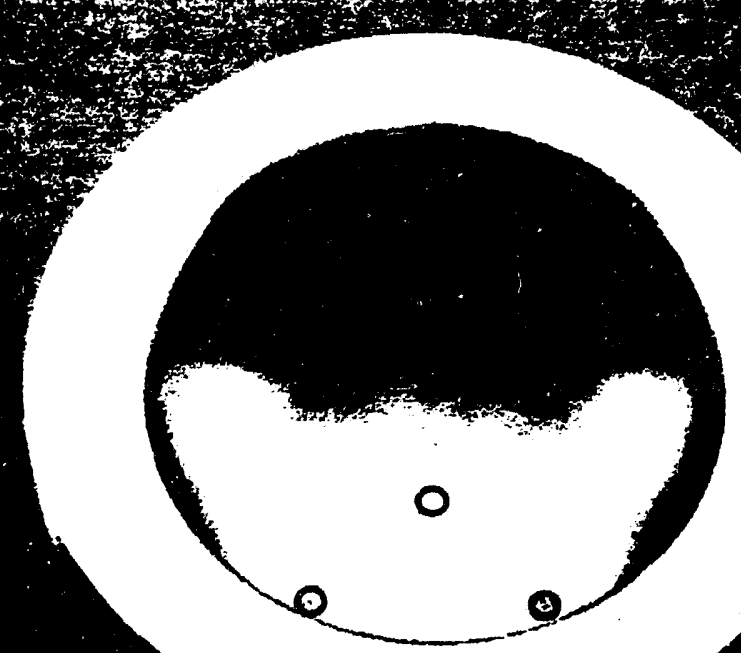

Inches

1

$0^{\mathrm{cm}} 1$

2

Figure 11. Stainless steeVair-gap insert with TEMPLUGs installed 


\section{Acknowledgments}

The authors wish to thank the National Renewable Energy Laboratory for financial support of this work. Thanks also to D.E. Blair, J.C. Wilkinson, and D.H. Hall for their help in setting up and running experiments; to R.L. Graves, R.N. McGill, and N. Domingo for their consultation and guidance; and to

Barbara Saiter of.LLorizol for providing the methanol lubricity additive.

References.

Beardsley, M.B. and H.J. Larson. 1992. Thick Thermal Barrier Coatings For Diesel Components. DOENASA Report.

Frank, R.M. and J.B. Heywood. 1991. "The Effect of Piston Temperature on Hydrocarbon Emissions from a Spark-Ignited Direct-Injection Engine." Society of Automotive Engineers Paper No. 910558.

Giovanetti, A.J. , J.A. Ekchian, J.B. Heywood, and E.F. Fort. 1983. "Analysis of Hydrocarbon Emissions in a Direct Injection Stratified Charge Spark Ignition Engine." Society of Automotive Engineers Paper No. 830587.

Heywood, J. B. 1988. Internal Combustion Engine Fundamentals, New York: McGraw-Hill Publishing. Incropera, F.P. and D.P. DeWitt. 1981. Fundamentals of Heat Transfer. New York: John Wiley and Sons.

Kahl, W.K. 1989. "Thermal Barrier Effects on Performance and Emissions of a Methanol Fueled DI Engine." Society of Automotive Engineers Paper No. 892163.

Lipari, F. and D. Keski-Hynnila. 1986. "Aldehyde and Unburned Fuel Emissions from Methanol-Fueled Heavy-Duty Diesel Engines." Society of Automotive Engineers Paper No. 860307.

Norris-Jones, S.R. and J.T. Russell. 1982. "FM - A High Efficiency Combustion System for the Future Light Duty Engine?" Society of Automotive Engineers Paper No. 820760.

Weast, R.C. , M.J. Astle, and W.H. Beyer, eds. 1984. CRC Handbook of Chemistry and Physics. Boca Raton, FL: CRC Press, Inc..

Wood, C.D. 1978. "Unthrottled Open-Chamber Stratified Charge Engines." Society of Automotive Engineers Paper No. 780341. 
Public reporting burden for this collection of information is estimated to average 1 hour per response including the time for reviewing instructions, searching existing data sources, aspect of this collection of intormation, including suggestions for reducing this burden, to Washington Headquarters Services, Directorate for information Operations and aeports, 1215 Jefferson Davis Highway, Sulte 1204, Arlington, VA 22202-4302, and to the Office of Management and Budget, Paperwork Reduction Project (0704-0188), Washington, OC 20503.

\begin{tabular}{|l|c|l}
\hline 1. AGENCY USE ONLY (Leave blank) & $\begin{array}{c}\text { 2. REPORT DATE } \\
\text { July } 1994\end{array}$ & $\begin{array}{c}\text { 3. REPORT TYPE AND DATES COVERED } \\
\text { Subcontract Report }\end{array}$ \\
\hline
\end{tabular}

\section{TITLE AND SUBTITLE}

Effects of Piston Surface Treatmentson Pertormance and Emisisions of a Methanol-Fueled, Direct Injection, Stratified Charge Engine

.

6. AUTHOR(S)

B. West anó J. B. Green

7. PERFORMING ORGANIZATION NAME(S) AND ADDRESS(ES)

8. PERFORMING ORGANIZATION REPORT NUMBER

Oak Ridge National Laboratory

Oak Ridge, Tennessee $37831-6285$

DE94011851

9. SPONSORINGMONITORING AGENCY NAME(S) AND ADDRESS(ES)

10. SPONSORING/MONITORING AGENCY REPORT NUMBER

National Renewable Energy Laboratcy

1617 Cole Boulevard

Golden, CO 80401-3393

NRELTP-425-6161

11. SUPPLEMENTARY NOTES

12a. DISTRIBUTION/AVAILABILITY STATEMENT

National Technical Information Service

U.S. Department of Commerce

5285 Port Royal Road

Springfield, VA 22161

\section{ABSTRACT (Maximum 200 words)}

The purpose of this study was to investigate the effects of thermal barrier coatings and/or surface treatments on the performance and emissions of a methanolfueled, direct injection, stratified charge (DISC) engine. The primary focus of the study was to examine the effects of various piston insert surface treatments on hydrocarbon ( $\mathrm{HC}$ ) and oxides of nitrogen $\left(\mathrm{NO}_{\mathrm{x}}\right.$ ) emissions. Four different piston bowl inserts were tested in the experiment: aluminum, stainless steel with an air gap, and two stainless steel/air-gap inserts with coatings. For the range of operation lested, the stainless-steel/air-gap insert produced the lowest emissions index

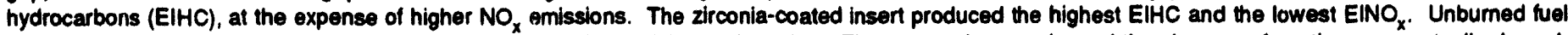
emissions for the coated inserts were improved by the addition of the seal-coating. These experiments showed that the use of coatings can actually degrade unburned fuel emissions, while improving oxides of nitrogen emissions. Results also reinforced the importance of using seal-coats with sprayed coatings, as observed by other research teams.

\section{SUBJECT TERMS}

DISC engine, hydrocarbon emissions, oxides of nitrogen emissions, piston bowl inserts, seal-coats 17. SECURITY CLASSIFICATION
OF REPORT

\section{SECURITY CLASSIFICATION OF THIS PAGE}

\section{SECURITY CLASSIFICATION OF ABSTRACT}

15. NUMBER OF PAGES

18

16. PAICE CODE

A03

20. LIMITATION OF ABSTRACT

NSN 7540-01-280-5500

Standard Form 298 (Rev. 2Prescribed by ANSI Sid. 23 S 

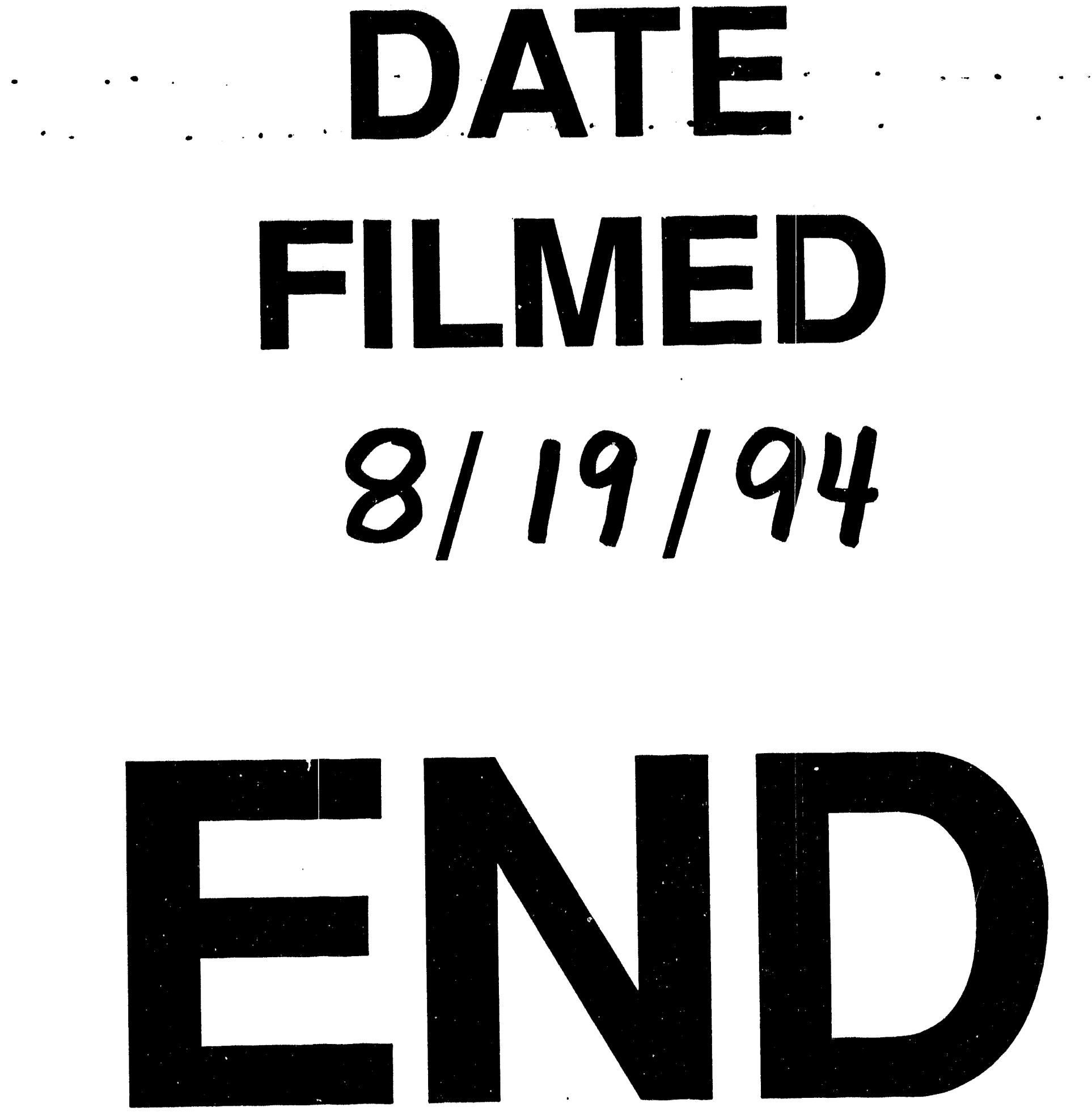

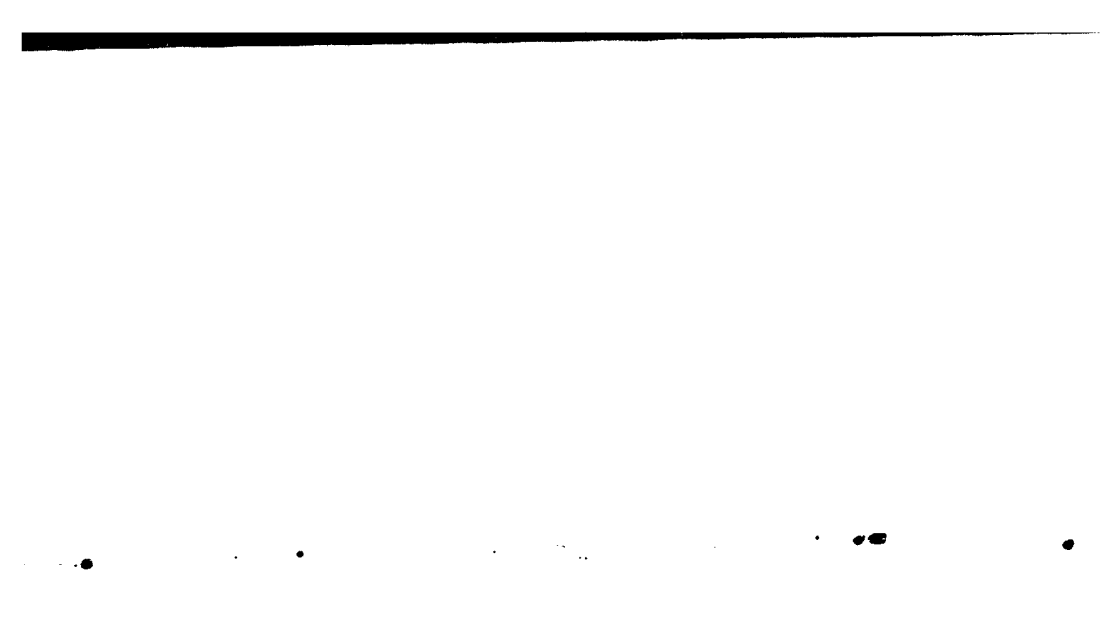

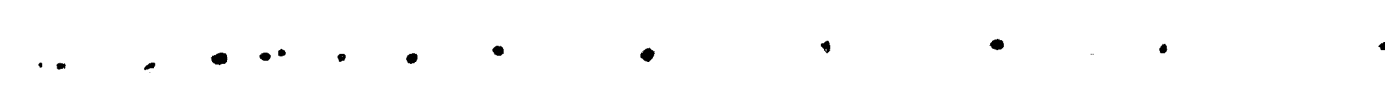

